\title{
Gender in Literature: Crossing the Lines of Individuals in a Philippine Fiction
}

\author{
Mildred M. Crisostomo ${ }^{1}$ and Mark Joseph B. Layug ${ }^{1}$ \\ ${ }^{1}$ College of Education, Don Honorio Ventura State University, Phillipines
}

\begin{abstract}
Under Gender Criticism, the researchers analysed Carlos Bulosan's My Father Goes to Court to unveil the biases, stereotypes, issues, and tendencies as regard gender through the roles played by the characters in the story. Results show that on the surface, the male characters portrayed their roles based on what the society and culture accorded or dictated to them as authoritative, powerful, and dominant. Similarly, female characters were projected as powerless, weak, affective, and secondary to men. However, consciously or unconsciously, both characters crossed the borders and the lines of each other by performing roles not expected of them. On the one hand, male characters growled down to others, laughed their hearts out, and were protected. Then, on the other hand, female characters exercised power, showed leadership, manifested decision-making skills, and served as protectors. The researchers further revealed that gender is not a role to be played but an activity to be complete to avoid setting limits to any person's tendencies. A study using the same literary text is recommended to continue its afterlife.
\end{abstract}

Keywords: Gender Criticism; Role Playing; Stereotypes; Tendencies

This is an open access article under the CC-BY-NC license.

\section{INTRODUCTION}

The Bible is very explicit and detailed when it comes to the creation of the first man and woman. God, after creating man, thought that it was not good for the latter to be alone and therefore out of one of his ribs, He created the woman expecting them to do complementary, supplementary, and mutually benefitting functions.

The man and the woman were created. But literature which is considered to be a narrative of possibilities may speak over and above or probably even beyond what was already stated; individuals who are proud of their phallic symbol; those who cry out loud of their yonic sign; and those who prefer either/ neither including those who can consciously or unconsciously function as both.

Gender is one of the most interesting topics when it comes to research because it is a relative issue. It calls the attention of not only the government and academic institutions but also various sectors and even almost every individual.

With gender and equality as resounding advocacy, especially at present, more and more issues surfaced, and the call for equality and equity has opened the minds and called the attention of many.

Crafting of additional laws and orders safeguarding women in the workplaces, schools, and at home; provision of a wide array of opportunities to both men and women where the latter could 
showcase her ability and authority; production of creative works via multi-media or various platforms; and provision of an avenue for leadership where equality and equity can be both enjoyed by women are just a few of the many leaps pertaining to gender equality that the whole world has taken, so far.

Literature which is an avenue for all possible expressions of deep-seated desires and aspirations serves as a rich repository of male and female thought processes and motifs. This is usually seen from the contention of the author, which is further revealed through his/her themes, tones, characterization, and motivation. In other words, it is but necessary and fitting that pieces of literature be read again to find these relevant contentions about men and women affected or not by their gender.

\section{LITERATURE REVIEW}

A lot of researches about gender has been conducted in the past. Others are showing the female gender as the stronger sex. Few are highlighting that women can be equal to men. While many are portraying that women are of submissive and inferior nature and status.

The levels of gender equality and women empowerment are best explained by Longwe in her Women's Empowerment and Gender Equality Framework (UNICEF 1994 cited in FPW, pp. 6-7) through welfare, access, conscientization, participation, and control.

\section{Welfare}

This is where empowerment is viewed as women and girls' improvement of physical condition. This first aspect addresses the men and women, boys' and girls' physical and material well-being.

\section{Access}

This is entitlement accorded to individuals by different agencies like the state and other systems like market and kinship by ensuring that all resources, human and material, are made available to both sexes.

\section{Conscientization}

This contends that the division between genders, differences in their gender roles are beyond the principle of the natural order; instead, they are determined by a socially constructed system of discrimination. Conscientization, therefore, challenges this stereotypical activity towards women. Such can be altered if only given attention.

\section{Participation}

This aspect addresses the obvious and apparent phenomenon of inequality. Such could be seen in the government, where men outnumbered women in terms of legislation. An apparent example of inequality is visible in sectoral leadership. Women are also seen as passive beneficiaries of welfare and access; thus, to empower them is to provide them chances for equality-individuals who can lead, make a difference, and effect change. 


\section{Control}

As to control, no one should be seen as in the position of dominance. When women are given a chance to take part in the most important functions of any organization or a system like production, they will also be given the opportunity to contribute to success in any endeavor. To achieve control equality means gender balance. If men are given a chance to do decision-making, women must enjoy the same, too. It is only through the giving of opportunities to women to control that they would be empowered thus could enjoy equal access to resources.

In Simone de Beauvoir's words, both genders are not born; they are made. Because of this thought, changing roles and functions can be performed by both if only they will not be placed inside a box or not become a victim of stereotypical assertions (Butler 1993).To assign them as male or female is to delimit their capacity to perform in society.

Meanwhile, West and Zimmerman (1987) also asserted that we are born with our gender, and it is not something we have, but something we do - something we actuate (Butler 1990).

Gender needs to creep in, and voices that were dumped and suppressed for the longest time by both history and literature are gradually making their way up to be heard. Readers who created a definite paradigm for textual interpretation, which tends to overlook individualities that contribute to the way we perceive genders and unfortunately handed down and being applied up to present time, are destined to sit back and re-read.

According to Livia (2000), gender study in literary texts is more than formalistic or stylistic analysis. It covers investigations of men and women and their representations, symbols, and functions. The output, like literary models, must settle to us what is happening in the real world between men and women.

In texts written and read then and now, the roles men played in the lives of women, in their families, and in society were commonly celebrated, while the roles that women play in the lives of men, their children, and the society were of ancillary in nature and usually overlooked. Whether celebrated or overlooked, there were and would always be male and female characters only in a text.

Confucian teaching, which is perfectly reflected in his Analects, seemingly is in consonance with the notion that women are second-class citizens. Confucius himself, on his analects, said that "a good woman is submissive and subtle."

Realizing the importance of this disjuncture between economic class and sex class for women, Maxine Molyneux (1984) argues in an often-cited article that there are no "women's interests" in the abstract that can unify women in political struggle. Instead, she theorizes that women have both "practical gender interests" and "strategic gender interests." Practical gender interests are those that women develop because of the sexual division of labor, which makes them responsible for the nurturant work of sustaining the physical and psychological well-being of children, partners, and relatives through caring labor. Such practical gender interests, because they tie a woman's conception of her own interests as a woman to those of her family, support women's popular movements for food, water, child and health care, even defense against state violence, which ally them with the economic class interests of their family. Strategic gender interests, on the contrary, may ally women across otherwise divided economic class interests since they are those, 
like rights against physical male violence and reproductive rights, which women have as a sex class to eliminate male domination.

Eviota, in her paper "Sex and Gender in Philippine Society," described women's compassionate and affectionate gender by being timid, passive demonstrative, loving, patient, selfless, and peacemaker/keeper. Women as mothers and wives are predestined roles. They can also be peacemakers. Furthermore, Gill said that women were traditionally portrayed on television as sensitive, passive, and domestic. Women were also considered empowered and liberated.

Basotia \& Kothari (2020) quoted Elizabeth V. Spelman (1988) in her book Inessential Women: Problems of Exclusion in Feminist Thought says,

some of the differences among women carry with them differences in privilege and power. Such differences may become problematic for privileged women as the occasion for fear, shame, and guilt. In such circumstances, the "problem of difference" is really the problem of privilege. (p. 90).

More so, Tarrayo (2015) strengthened that women find their value by highlighting the position they occupy in a patriarchal society.

Carol Gilligan (1982) claims that women and girls tend to use a different form of ethical reasoning - she terms this the "ethics of care" - than men and boys who use ethics of justice. Some have argued that this different ethical approach is due to women's caring sensibilities that have been developed by the sexual division of labor (Ruddick 1989).

Interestingly, Lakoff statesmen and women differences in terms of expressing themselves. She describes male language as authoritative or stronger of a higher state and more listened to. Meanwhile, women's speech style is said to be the total reverse of that of men. It is comprised of features that elaborate weakness. These include expressions of uncertainty, unconfidence, and politeness' (Lakoff in Finch: 2003, p.137).

Talbot claimed that cross-cultural phenomenon brought about the desire of men to rule women. This is one of the setbacks of difference theory which, according to Johnson and Meeinhof (1997, p.9), falls short in surfacing the reason why men and women are products of tension-based subcultures. Meanwhile, Crawford (1995, p.1) explained that the two different groups" are doomed to be conflicting each other unless they attend to their differences. These differences affect not only their minds and emotions but also their manner of expressing themselves on various platforms.

Wardhaugh (2010) stresses that women are into the use of more compliments and polite ways of saying things avoiding the world of men, which is masculine, powerful, and authoritative. Meanwhile, men are less affectionate (p.343). Congruence to what was stated, Tannen (1990) confirmed that public speaking is the stage of men. Meanwhile, the same comfort is enjoyed by women as men when in private settings.

In addition, Wardhaugh (2010) quoted Homes (1998) relative to the five testable claims between men and women:

1. Language use is determined by men's and women's different patterns.

2. Men do not give much attention to the effective function of communication or interaction. Women do.

3. Linguistic devices that tend to express solidarity are commonly used by women.

4. While women choose to communicate to stabilize or improve solidarity formally, men focused more on how they could sustain and accelerate their authority or stature.

5. The former's flexibility is also seen in stylistics more than the latter.

41 
Fun (2020), in her study Rewriting the Feminine Construction of a Nation in Comfort Women by Nora Okja Keller, concluded that Keller rewrote the feminine construction of a colonized nation by creating women characters who represented not feminization of a colonized nation but who proclaimed themselves as the nation itself, transcending the perception of women as commodities to be looted or to be protected against looting. Keller's narrative effectively posed a challenge to and revised patriarchal definition and notion of the meaning of a nation.

Obviously, in almost all literature, men and women are boxed and imprisoned by stereotypes set by both society and culture, and as such, they are expected to perform and function according to what the aforementioned expects of and dictates to them. Men as strong while women as weak. Men are as powerful while women are as powerless. Men as leaders while women as followers. This is a status quo that needs to be disturbed and challenged to discover potentials beyond expectations, capacities beyond imagination, abilities beyond assumptions.

The researchers aimed to unveil biases and issues as regards gender through the roles played by the characters in Carlos Bulosan's My Father Goes to Court. Specifically, they explored the theme, language, conflict, and symbols present in the stories to surface the multifaceted and mutuallybenefiting roles and tendencies that both men and women can play as individuals.

\section{RESEARCH METHOD}

Since this study involves a literary text, the researchers conducted textual analysis specifically, giving a high premium on the roles played by the characters in the short story. Mindful about the text, which is Philippine fiction, the researchers made it a point that the world in the text and the world of the text were also explored.

To achieve the objectives of this study, the researchers utilized gender criticism which focuses on the characters' role-playing as they construct gender and sexuality. Gender criticism suggests multifaceted power playing and not top-down or patriarchal as what and how it is commonly presented. In other words, heterosexuals have homosexuals' tendencies or vice-versa. Simply, men have tendencies to function as women; women have tendencies to function as men.

\section{FINDINGS AND DISCUSSION}

This fiction is a narrative satire that tells the story of a poor family who lives beside the house of a rich family. Despite the poverty of the former, their family remains happy and healthy as they delight in the humor and company of each other while enjoying the delicious aroma of the banquet that is regularly served to the rich family in the adjacent house. On the other hand, the rich family eventually becomes sickly and starts to blame their misfortunes on the poor family. Because of this, the patriarch of the rich family decides to bring the matter to court by accusing the poor family that the latter has stolen the spirit of their food and wealth, which has resulted in their mishap.

The poor father, along with his wife and children, willingly goes to court to defend his family even without legal counsel. The lawyer of the rich family, together with the rich patriarch, directly tells the judge that the poor people are to be blamed for their sickliness as they tend to rob the rich family's spirit of their wealth and food. The poor father vehemently denies the accusation, but he readily admits that he and his family have savored through their sense of smell the inviting aroma of the delicious food that is cooked and served from the other house. 
Hearing the rich man's argument, the poor father fills his son's straw hat with centavo coins which he collects from his wife and children and walks it around the court toward the room across the hall. He shakes the hat, and the sweet tingle of the coins fills the entire courtroom. He then proceeds in front of the complainant and asks if he has heard the beautiful sound of the coins. The rich man answers him with a yes, and the poor father tells him that his family has already paid for the heavenly aroma of their delicious food with the sweet and beautiful sound of the coins. The rich man is dumbfounded and drops to the floor. The judge immediately dismisses the case and laughs out loud with the poor family.

\section{The Stereotypes}

This story is an example of prose fiction that speaks so strongly of the patriarchal inclination of the Filipinos. This is manifested by the major roles played by the two fathers in the story. The father of the poor family had displayed utmost authority when he defended and outwitted the patriarch and the lawyer of the rich family. He has confidently presented himself on behalf of his entire family, which eventually resulted in the dismissal of the case. More so, the father of the rich family has been the dominant and antagonistic character for the other party from the start until the end of the story.

\section{The Switching of Roles}

Mother as the Protector

Apart from the ascribed patriarchal status, three other ascribed master statuses, which are often stereotyped among men, were also presented in the story - the policeman, the lawyer, and the judge. Law enforcement, which is an essential aspect of any society, is almost always tagged among male characters. On one hand, such is also put in the obvious through the masculine references and pronouns used toward these three.

On the other hand, the role of the mother has been very significant, especially on the side of the poor family. The mother has been mentioned a number of times in various circumstances - both during happy and trying times.

In addition, the part which narrates the poor family's father sitting at the center of the court while the mother sits by the door is an obvious switching of roles. Considering the surface meaning, the father seated on a chair may connote his leadership or command, especially that the chair is placed in the center of the courtroom while the mother occupying a chair by the door symbolizes her support function to the father. However, doors as archetypes are associated with privacy, control, and protection. Guards and policemen are usually seen standing or sitting by the door for the protection of those insides. Simply put, the role of the father, which is to protect the family, is now accorded to the mother while the mother who is to be protected is portrayed and enjoyed by the father.

Corollary to the aforementioned, Tarrayo (2015) strengthened that women valorise themselves by magnifying their seats and values in a patriarchal society. He added that the woman is more than a house-based partner. She is a carrier and nurturer of humanity. Therefore, she wants to be known as a thinker, an able individual who can be an active player and contributor in a society where she belongs.

\section{Father as the Clumsy One}


It is also very noticeable that the presence of the mother in the poor family is always juxtaposed with the presence of the father. This juxtaposition suggests that the mother's role, especially among marginalized families, is of great significance. The mother in poor families does not only function as strong support but rather the equal of the father in family management and decision-making processes. On the other hand, the mother in the rich family was only mentioned once in the story. As a matter of fact, the lone mentioning of the mother in the rich family only reflected her weakness which has been associated with the eventual demise of the rich man's health. This textual evidence may imply that the role of the mother in affluent or well-to-do families may become less noticeable since there is no need for intensified support to the father of the household.

In relation to the aforesaid, RA 7192 (Rule 1, Section 2) acknowledges that women can play a significant role in nation-building and therefore must be accorded equal chances and opportunities to function well by allotting budget or funds that support programs, projects, and activities involving them.

Another interesting point in the story is the persona's consistent usage of the pronoun "we", which always includes all the siblings, both male and female, in all the recounting of events. Because of this, the gender of the persona was not really identified, for there is no concrete reference as to the determination of the storyteller's gender. Apart from the persona's age at the time of the occurrence, no other information about the persona can be directly extracted from the text. In addition, the exact number of siblings was not specific; one can only argue that the persona has more than one brother and more than one sister, as this was made clear at the onset of the story. The same is true with the children of the rich man, for there was no exact reference as to the number of his children.

The parallelism of gender and number generality may also be observed among the servants. There was neither direct mentioning of the gender nor the number of the servants in the house of the rich man, even if they were mentioned a lot of times in the text. In addition, the spectators in the courtroom were also not identified as to number and gender. This consistency in the literary text points out the balance between and among the collective characters in relation to their gender and number, regardless of their role and significance in the story. With all these in mind, one can only infer that society generally confers specific roles and statuses to people in relation to the specificity of their gender. However, some roles and statuses are generally accepted to be taken both by males and females. This role specification may somehow skew the balance between the two genders since the major master statuses in the story were specifically assigned to the male gender.

On the contrary, Lakoff states the men and women differences in terms of expressing themselves. She describes male language as authoritative or stronger of a higher state and more listened to. Meanwhile, women's speech style is said to be the total reverse of that of men. It is comprised of features that elaborate weakness. These include tendencies of uncertainty, unconfidence, and politeness (Lakoff in Finch: 2003, p.137).

\section{Mother as the Authority}

Despite the general and specific conferment of roles and master statuses toward the two genders, the literary text also revealed that certain characteristics which are accorded to men might also be observed among women, whilst certain characteristics which are accorded to women may also be observed among men. The mother in the poor family has displayed unprecedented authority 
in the household, which even went beyond the supremacy of the father. Her character is more serious and authoritative in nature.

In some parts, the mother's power went at par with the supposed rule that is commonly exercised by the father. Here, the mother went to the extent of beating the male offspring with her little fists. Beating is usually associated with men because it requires a great deal of physical strength which is naturally possessed by males. Her compelling supremacy may also be observed in her disposition and intellectual capacity as manifested during the daughter's pregnancy prank.

The mother was the first to reach the daughter, and her first instinct was to calm the kid. She did not panic, and she handled the situation the right way. Her intelligence encompassed that of the father, as reflected on the statement that she posed when the daughter told them that she was pregnant. The father's statement "Don't be a fool!" is harsh and irrational, while the mother's response - "You're only a child" is sympathetic and wise.

As quoted by Wardhaugh (2010) from the five (5) contentions of Holmes (1990), one of which is that women are affective communicators more than men. This claim was clearly manifested by the mother based on how she responded to the revelation of the daughter. Noteworthy to mention, too, is the fact that the mother appeared to be the one making decisions when it comes to sensitive issues or problems confronting the family, as revealed by her composed and unshaken reaction to the situation. Such attribute is normally seen in men, in fathers.

\section{Father as the Less Serious One}

Meanwhile, laughing out loud is commonly associated with women, especially when they are jesting with acquaintances. Men are more likely to be civil and serious. However, the poor father in the story was noted to have frequently been laughing and jesting in various instances. His playful attitude and character somehow go against the projected seriousness of fatherly images, especially in patriarchal societies.

Apart from the father, two other male characters were identified to have had a penchant for laughing - the judge's uncle and the judge.

In a nutshell, the analyzed fiction has presented the multifaceted role conferment between men and women in society. Some roles are gender-specific, for these roles are usually stereotyped to a certain gender. Some roles are generally accepted both for males and females since they do not cause any altercations on socio-cultural norms. Tendencies of men to function as women and tendencies of women to function as men were very apparent in the story. Implicitly, there are still some gender-specific traits and attitudes that may be unconsciously shared by men and women despite society's tendency to accord them to a particular gender. Clearly, as quoted from UNICEF (1994), empowered women enjoying equality via the four dimensions explained previously were enjoyed or seen played by the mother in the story. Thus, to consider gender as a role is tantamount to setting limitations to what men and women can do, project, and explore. But, to consider gender as an activity means removing the box that imprisoned both men and women to stereotypes and notions. Therefore, giving them much freedom to discover themselves and be the best that they can be in areas left unexplored as they were customarily accorded to men and women as isolated individuals. 


\section{CONCLUSION}

Considering the results of the analysis, the following are inferred. A person should not be defined based on his/her gender, especially when gender is seen only as a role. The story clearly showed that a person could function or act beyond what society and culture dictate. They can break stereotypes and biases because they can have tendencies to function out of what is expected. From the stereotypes, the roles of the father and mother evolved and switched. The male characters in the story portrayed the typical roles of a man. However, out of their portrayal of their roles as men, they were able to show, too, that they either consciously or unconsciously acted or functioned as women. There were circumstances in the story where male characters crossed the lines of women. They glowered down at others instead of meeting the eye to eye. They laughed their hearts out like women. They enjoyed protection instead of giving protection. The same is applied to female characters in the story. There were a lot of instances in the story where female characters functioned as men based on their leadership, decision-making abilities, characteristics, and speech styles. They projected their authority in the household. They excelled in decision-making practices. They protected the family. It is logical to say, therefore, that the provision of RA 7192, which is the giving of equal opportunities to men and women to switch or try each other's roles both in the secular and non-secular, is practiced and apparent even in stories. This concretized the idea that seeing men and women fairly and squarely is a reality and can be enjoyed by both sexes if only it would become a conscious consideration at all times.

Indeed, from Mars are men and from Venus are women but, let us not forget though that there is Earth in between where both can live together in harmony, peace, and unity. Any person, regardless of his/her gender preference, must not be placed inside a box or be limited by any stereotypes or cultural accords. Each one must be seen, treated, and appreciated as able with full of tendencies. This may lead to a better, if not an improved, valuing of a person. The literary text may be explored again using different literary approaches to continue its afterlife. Its holistic beauty and essence as a piece of literature may not be revealed if its analysis ends here. Further analysis is therefore encouraged.

\section{ACKNOWLEDGMENT}

Grateful acknowledgment is forwarded to our respective families, our College, our University, and our ultimate Source of Wisdom for giving us the inspiration, opportunity, and ability to complete this research that belongs to a discipline that is close to our hearts.

\section{REFERENCES}

Basotia, S. and Kothari, A. (2020). Postmodern Feminist Perspectives in Eat Pray Love. Pertanika J. Soc. Sci. \& Hum. 28 (4): 2929 - 2942 (2020).

Butler, Judith. 1990. Gender Trouble: Feminism and the Subversion of Identity. New York and London: Routledge.

Butler, Judith. 1993. Bodies that matter: Routledge.

Crawford, M. (1995). Talking Difference - on gender and language. SAGE.

Eviota, E. (Ed). (1994) Sex and Gender in Philippine Society. San Miguel, Manila: National Commission on the Role of Filipino Women. Retrieved from http://library .pcw.gov.ph 
Finch, G. (2003). Word of Mouth. An Introduction to Language and Communication. Palgrave Macmillan. Pp. xii, 228.

Fun, C.S. (2020). Rewriting the Feminine Construction of a Nation in Comfort Woman by Nora Okja Keller. Pertanika J. Soc. Sci. \& Hum. 28 (4): 2989 - 3002 (2020)

Gilligan, Carol, 1982, In a Different Voice: Psychological Theory and Women's Development, Cambridge: Harvard University.

Holmes, J. (1998). Signaling gender identity through speech. Moderna Speak 92, (2) 122-128.

Lakoff, R. (1975). Language and Woman's Place. Language in Society, 2(1), 45-80. New York: Harper and Row.

Livia, Anna 2000: Pronoun Envy: Literary Uses of Linguistic Gender. New York: Oxford University Press.

Molyneux, Maxine, 1985, “Mobilization without Emancipation? Women's Interests, State and Revolution", Feminist Studies, 11(2): 227-254. Reprinted in Molyneux 2001: 38-59.

---, 2001, Women's Movements in International Perspective, New York: Palgrave.

Republic Act 7192. AN ACT PROMOTING THE INTEGRATION OF WOMEN AS FULL AND EQUAL PARTNERS OF MEN IN DEVELOPMENT AND NATION-BUILDING AND FOR OTHER PURPOSES.

Ruddick, Sara, 1989, Maternal Thinking: Toward a Politics of Peace, Boston: Beacon.

Sara Longwe, Women's Empowerment and Gender Equality Framework (UNICEF 1994 cited in FPW, pp. 6-7)

Spelman, E. V. (1988). Inessential woman: Problems of exclusion in feminist thought. Boston, USA: Beacon Press (MA).

Talbot, M. (1998). Language and Gender - An Introduction. Polity Press.

Tannen, D. (1990). You just don't understand: Women and men in conversation. New York: William Morrow.

Tarrayo, V. (2015) The Woman in the Mirror: Imaging the Filipino Woman in Short Stories in English by Filipino Woman Authors. International Journal of English and Translation Studies, 3(1), 109-124. Retrieved from http://www.eltsjournal.org

Wardhaugh, R. (2010). An introduction to sociolinguistics. Malden, MA: Wiley-Blackwell.

West, C., \& Zimmerman, D. (1987). Doing Gender. Gender \& Society, 1, 125151.http://dx.doi.org/10.1177/0891243287001002002 